\title{
Vokalni citati slavonskog melosa u skladbi Vukovarski requiem autora Davora Bobića
}

Zdravko Drenjančević* zdravko.drenjancevic@uaos.hr https://orcid.org/0000-0002-8413-1715 https://doi.org/10.31192/np.19.1.8

UDK: 78(497.54)

78Bobić, D.

355.48(497.544Vukovar)"1991/1995":78.082.1 Izvorni znanstveni rad / Original scientific paper

Primljeno: 14. srpnja 2020. Prihvaćeno: 2. studenog 2020.

Nakon Prvoga svjetskog rata, pojavom neonacionalnog smjera, započinje razdoblje značajnije primjene slavonskog melosa u umjetničkoj glazbi. Od 50-ih godina prošlog stoljeća ta je primjena, različitim intenzitetom, prisutna sve do danas pa tako glazbenom opusu nadahnutom slavonskim melosom pripada više od 60 skladateljskih ostvarenja. U sklopu našeg istraživanja tog opusa izdvojili smo skladbu varaždinskog skladatelja Davora Bobića pod nazivom Vukovarski requiem. Na stvaranje ove četverostavačne simfonije skladatelja su potaknula ratna stradanja grada Vukovara za vrijeme Domovinskog rata. Unutar opusa nadahnutog slavonskim melosom samo prvi stavak Bobićeve simfonije, Predskazanje, sadrži vokalne citate u izvedbi izvornog ženskog pjevačkog sastava. To je pobudilo naš znanstveni interes te postalo temom ovog rada. Skladatelj preuzima i razrađuje melodiju tradicijskog žetvenog napjeva Tri jetrve žito žele, naglašavajući citatom pripadnost grada Vukovara Slavoniji. Dokazavši podrijetlo preuzetog citata, analitički smo prikazali načine njegove primjene te ulogu izvornog ženskog pjevačkog sastava u stvaranju asocijacija slavonskog melosa.

Ključne riječi: requiem, simfonija, slavonski melos, vokalni citati.

\footnotetext{
* Dr. sc. Zdravko Drenjančević, Sveučilište J. J. Strossmayera u Osijeku, Akademija za umjetnost i kulturu, Kralja Petra Svačića 1F, HR-31000 Osijek.
} 


\section{Uvod}

Od dvadesetih godina prošlog stoljeća generacija skladatelja, na čelu s Dobronićem, Lhotkom, Odakom, Širolom, Gotovcem, Baranovićem i dr., predvodi neonacionalni smjer u glazbi s uporištem u folkloru i tradicijskoj baštini. ${ }^{1}$ Usporedno s proučavanjem i primjenom značajki našeg folklora povećava se zanimanje skladatelja i za slavonski melos² (Zlatić, Širola, Kunc, Papandopulo, Matz, Dobronić i dr.). ${ }^{3}$ Nastaje veći broj skladateljskih ostvarenja čime razdoblje neonacionalnog smjera ujedno čini i najplodonosnije razdoblje unutar opusa nastalog na obilježjima slavonskog melosa. U drugoj polovici 20. stoljeća ta su obilježja i dalje prisutna (Pibernik, Bradić, Vidošić, Marković, Josipović) te ih u glazbenom izričaju dijela skladatelja bilježimo sve do danas (Bobić, Makar, Uhlik, Ščekić).

Bogat i zanimljiv glazbeni opus nadahnut slavonskom tradicijskom glazbom obuhvaća različita glazbena područja, oblike i vrste. Sadrži orkestralna, komorna, koncertantna, solistička, scenska, vokalno-instrumentalna i vokalna djela.

Tijekom proučavanja ovog potpuno neistraženog glazbenog područja izdvojili smo skladbu varaždinskog skladatelja Davora Bobića pod nazivom Vukovarski requiem. Načinom citiranja tradicijskog napjeva ovo simfonijsko ostvarenje jedinstven je primjer na polju simfonijske glazbe nadahnute slavonskim melosom.

\section{Simfonija Vukovarski requiem [op.80]}

Varaždinski skladatelj Davor Bobić pripada srednjoj generaciji hrvatskih skladatelja. Širina njegova bogatog i raznovrsnog opusa proteže se od orkestralnih, koncertantnih i komornih djela, preko skladbi za solo instrument, vokalno-instrumentalnih i vokalnih skladbi sve do scenskih ostvarenja. U njegovu skladateljskom izričaju "progovara neoklasicističko-nacionalni idiom u službi usavršavanja izvodilačkog zanata i potvrđivanja nacionalnog identiteta«. ${ }^{4}$

Simfoniju Vukovarski requiem Bobić je napisao za naratora, alt i tenor solo, ženske narodne glasove, zbor i simfonijski orkestar, na stihove književnika Er-

${ }^{1}$ Usp. Stanislav TUKSAR, Hrvatska glazba od srednjovjekovnih kodeksa i Ivana Lukačića do 20. stoljeća, Nova prisutnost, 9 (2011) 1, 65-70, 70.

2 Pod pojmovima slavonski melos i slavonska glazba podrazumijevamo glazbene osobine Slavonije, Baranje i Srijema koji čine geografsku regiju Istočne Hrvatske.

${ }^{3}$ Usp. Zdravko DRENJANČEVIĆ, Elementi ljudske glasbe Slavonije $v$ delih skladateljev umetniške glasbe 20. stoletja, Ljubljana, Doktorska disertacija, 1. knjiga, Univerza v Ljubljani, Akademija za glasbo, 2011, 74-81.

${ }^{4}$ Nataša MARIČIĆ, Varaždinski skladatelji s kraja 20. stoljeća, u: Jelena HEKMAN (ur.), Hrvatska glazba u XX. stoljeću. Zbornik radova sa znanstvenoga skupa održanog u palači Matice hrvatske 22.-24. studenoga 2007., Zagreb, Matica hrvatska, 2009, 171-184, 171. 
nesta Fišera. Skladba je nastajala u razdoblju između 1991. i 2001. godine. Praizvedbu je doživjela 18. studenog 2004. godine u Koncertnoj dvorani Vatroslava Lisinskog u Zagrebu, na 13. obljetnicu okupacije grada Vukovara. Simfonija opisuje patnju herojskoga grada Vukovara 1991. godine, veliča njegove žrtve i osuđuje nedjela agresorske vojske.

Vukovarski requiem jedino je simfonijsko ostvarenje iz opusa nastalog na elementima slavonske tradicijske glazbe. Unutar četverostavačne formalne strukture samo prvi stavak, s podnaslovom Predskazanje, sadrži elemente slavonskog melosa. Sadržavajući vokalne citate u izvedbi izvornog ženskog pjevačkog sastava, djelo je jedinstven primjer unutar cijelog opusa.

U kontekstu cijele skladbe do izražaja dolazi vrlo smislena primjena elemenata slavonskog melosa u prvom stavku. Podnaslovom prvog stavka Predskazanje - Nagovještaj zla libretist Ernest Fišer jasno pogađa in medias res, sadržajno nagovještavajući glazbenu i verbalnu poruku simfonije, usmjerenu na patnje, rat i poginule žrtve. Izravnu sadržajnu poruku nalazimo i u drugom stavku simfonije, s podnaslovom Kalvarija Grada (odsjeci: Andante sostenuto, Largo, Vivo, Largo i Andante). Prisutnost religiozno-apokaliptičnih slika nalazimo u Fišerovu tekstu oplemenjenom Bobićevom glazbom. Naizgled mirniji, elegični treći stavak s naslovom Uznesenje - Razgovor dviju duša (tempo Andante sostenuto) djeluje još tragičnije jer poseže u onozemaljski prostor kada se duše odvajaju od umornih tijela. Četvrti stavak, s naslovom Requiem i u tempu Adagio, kao sjećanje i podsjetnik opet poseže u religioznu, ovozemaljsku sferu katoličkog bogoslužja.

Unutar takvog idejnog okvira posebno mjesto zauzima primjena slavonske tradicijske glazbe, što dodatno implicira pripadnost grada Vukovara Slavoniji.

U programskoj knjižici za praizvedbeni koncert nalazimo sljedeće:

»Simfoniju tvore četiri tematski bliska premda zvukovno različita stavka. Prvi stavak (s podnaslovom Predskazanje, a s ulomcima Adagio sostenuto, Adagio, Andante sostenuto, Vivace con fuoco, Poco meno mosso, Allegro moderato i Sostenuto) stroga je sonatna forma koja ne dopušta nikakva odstupanja, ujedno i jedini čvrst oblik unutar djela... Ostala tri stavka smještena su u okvire slobodno shvaćenih pjesama: dok su drugi i četvrti stavak trodijelne, treći je stavak dvodijelna pjesma. $\aleph^{5}$

Slavonski melos očituje se na dva načina: (1) primjenom glazbenog citata podrijetlom iz istočnog dijela Hrvatske, koji se javlja na početku Bobićeve simfonije te (2) karakterističnim načinom izvođenja ženskog pjevačkog sastava.

\footnotetext{
${ }^{5}$ Josip GUBERINA (ur.), Vukovarski requiem. Programska knjižica za koncert u Koncertnoj dvorani »Vatroslav Lisinski« u Zagrebu, 18. studenog 2004; urednica teksta D. Detoni, Zagreb, Hrvatska radiotelevizija 2004, 1-12 (nepag.), 8.
} 


\section{Slavonski tradicijski glazbeni citat u prvom stavku simfonije Vukovarski requiem}

Slavonski tradicijski žetveni napjev Tri jetrve žito žele skladatelj Bobić citira u Predskazanju, prvom stavku simfonije. Budući da se napjev pjevao po cijeloj Slavoniji, postoje njegove brojne inačice. U programskoj knjižici, tiskanoj za praizvedbu skladbe, navedeno je podrijetlo napjeva, »Hrvatska narodna pjesma iz Draža, Slavonija«. ${ }^{6} \mathrm{~S}$ velikom sigurnošću možemo pretpostaviti da je skladatelj posegnuo za dokumentiranim zapisom napjeva koji je Julije Njikoš zabilježio kod hrvatskih Šokaca u baranjskom selu Dražu. ${ }^{7}$
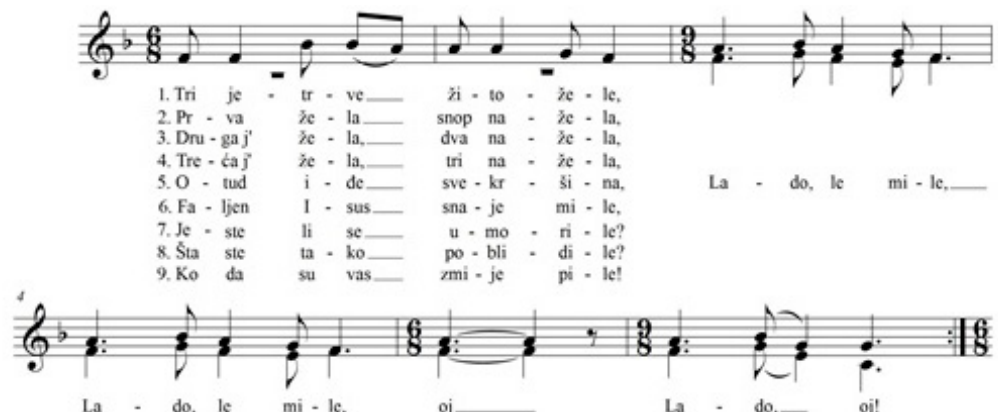

La - do, le mi - le, oj_ La - do, - oj!

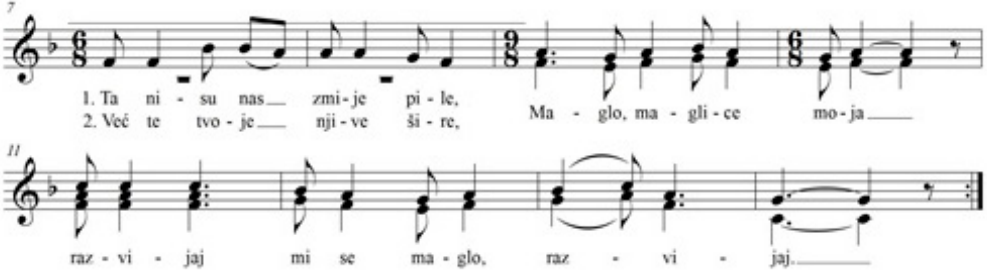

Slika 1: Tri jetrve žito žele (Draž), zapisao: J. Njikoš. ${ }^{8}$

U strukturi ove slavonske tradicijske pjesme jasno se razabiru dva gotovo simetrična odsjeka. Prvi šesterotaktni A odsjek (t. 1 - 6) i drugi, naizgled produženi, osmerotaktni A' odsjek (t. 7 - 14) sadržajno su bliski, što je istaknuto pri njihovu označavanju. Vremenska razlika kod izvedbe napjeva, nastala zbog deveterokratnog ponavljanja stihova prvog A dijela, još dodatno naglašava njegovu dvodijelnu strukturu. Nakon svakog stiha, koji je u osmercu (t. 1 -

\footnotetext{
${ }^{6}$ Guberina, Vukovarski requiem..., 11.

7 Usp. Julije NJIKOŠ, Oj Baranjo lipa i bogata: zbirka narodnih pjesama, plesova i običaja baranjskih Hrvata Šokaca za dječji, ženski, muški i mješoviti pjevački zbor i tamburaški orkestar, Zagreb, Program - Mi, 1996, 32; Mihael FERIĆ, Folklorna glazba Panonske plesne zone, Vinkovci, Kulturni centar »Gatalinka«, 2016, 155.

${ }^{8}$ Usp. Ferić, Folklorna glazba...,155.
} 
2), slijedi refren Lado, le mile... ${ }^{9}$ Kod posljednja dva stiha drugog A' odsjeka također nalazimo osmerce. Oni sadrže novi i duži otpjev Maglo, maglice moja, razvijaj... Tekst i oblik pjesme zahtijevaju naš dublji osvrt.

Iz sadržaja jasno je vidljivo da je riječ o obrednom napjevu koji se pjevao u vrijeme žetve. Međutim, glazbena slika ukazuje na antifonijsko pjevanje koje podsjeća na litanijske oblike, kod kojih se solist (stihovi 1 - 9 A odsjeka i $1-2 \mathrm{~A}^{\prime}$ odsjeka) izmjenjuje sa zborom. U Njikoševu zapisu to je naglašeno dodavanjem pauza u drugom glasu (t. $1-2$ i t. 7 - 8). Stalni grupni antifonijski otpjev Lado, le mile... (A odsjek) i Maglo, maglice moja (A' odsjek), suprotstavljen solistici, upućuju na stanovitu arhetipsku obrednu vezu iz prošlosti.

Prije glazbeno-analitičkog prikaza ovog napjeva donosimo njegovu metričku sliku.

Tablica 1. Analiza i metrički prikaz teksta tradicijske pjesme Tri jetrve žito žele.

\begin{tabular}{|c|c|c|c|c|}
\hline \multicolumn{2}{|c|}{$\begin{array}{l}\text { Stihovi i } \\
\text { melodijski motivi }\end{array}$} & \multirow{2}{*}{$\begin{array}{l}\text { Tekst pjesme } \\
\text { Tri jetrve žito žele, } \\
\text { La_do, le mile, } \\
\text { La_do, le mile, oj..., } \\
\text { La_do..., oj! } \\
\end{array}$} & \multicolumn{2}{|c|}{$\begin{array}{l}\text { Metrička slika } \\
\text { (kvantitativna metrika prema tekstu i } \\
\text { melodiji) }\end{array}$} \\
\hline $\begin{array}{l}\text { Stih } 1-9: \\
\text { Refren: }\end{array}$ & $\begin{array}{l}\mathrm{A} \\
\mathrm{a} \\
\mathrm{b}^{(\mathrm{a})} \\
\mathrm{b}^{(\mathrm{a})} \\
\mathrm{b}_{1}\end{array}$ & & $\begin{array}{l}8 \\
6 \\
8 \\
6\end{array}$ & $\begin{array}{l}\mathrm{u}-\mathrm{u}-\mathrm{u}-\mathrm{u}- \\
\underline{\mathrm{u}-} \mathrm{u}-\mathrm{u}- \\
\underline{\mathrm{u}-}-\mathrm{u}-\mathrm{u}-\underline{\mathrm{u}-} \\
\underline{\mathrm{u}}-\underline{\mathrm{u}}-\underline{\mathrm{u}}-\underline{ }\end{array}$ \\
\hline $\begin{array}{l}\text { Stih } 1-2: \\
\text { Refren: }\end{array}$ & $\begin{array}{l}\mathrm{A}^{\prime} \\
\mathrm{a} \\
\mathrm{b}_{2}{ }^{(\mathrm{a})} \\
\mathrm{b}_{2}{ }^{(\mathrm{a})} \\
\mathrm{b}_{1}\end{array}$ & $\begin{array}{l}\text { Ta, nisu nas zmije pile. } \\
\text { Ma_glo, maglice moja, } \\
\text { razvijaj_mi se maglo, } \\
\text { razvijaj. }\end{array}$ & $\begin{array}{l}8 \\
8 \\
8 \\
6\end{array}$ & $\begin{array}{l}\mathrm{u}-\mathrm{u}-\mathrm{u}-\mathrm{u}- \\
\underline{\mathrm{u}-} \mathrm{u}-\mathrm{u}-\mathrm{u}- \\
\underline{\mathrm{u}}-\underline{\mathrm{u}-} \mathrm{u}-\mathrm{u}- \\
-\mathrm{u}^{*} \underline{\mathrm{u}}-\underline{\mathrm{u}}-\end{array}$ \\
\hline
\end{tabular}

Tekst i melodija pjesme čine jedinstvenu cjelinu. Osim naglasaka unutar teksta, pri određivanju metričke strukture vodit ćemo se i kvantitativnim osobinama melodije, zajedno sa slogovima, što će biti odlučujući čimbenik u stvaranju metričke slike teksta pjesme. Kod takvog pristupa prikladnije je koristiti metriku u grčko-latinskom kvantitativnom, umjesto današnjem akcentuacijskom smislu. Promatramo li metričku sliku iz cjeline 'tekst-melodija', vidljiva je već spomenuta dvodijelna simetrija. Do izražaja dolazi jampski četverac kod kojeg se kratki i dugi slog mogu zamijeniti oblikom tzv. iracionalne zamjene jednim dugim slogom, što je bila praksa u kvantitativnoj grčko-latinskoj metrici.

\footnotetext{
${ }^{9}$ Lada: »mit. 1. u slavenskoj mitologiji, božica proljeća i ljepote 2. (lada) glazb. u prastarim slavenskim pjesmama, pripjev vezan uz slavljenje godišnjih doba, posebice proljeća « [Vladimir ANIĆ i dr., Lada, u: Ljiljana JOJIĆ, Ranko MATASOVIC (ur.), Hrvatski enciklopedijski rječnik, 5 (K-Ln), Zagreb, EPH - Novi Liber, 2002, 2004, 314].
} 


\section{Analitički pregled građe prvog stavka Vukovarskog requiema $i$ primjena slavonske tradicijske melodije}

Prvi stavak simfonije, Predskazanje, oblikovan je u formi sonatnog oblika. Prepoznatljive su dvije kontrastne teme.

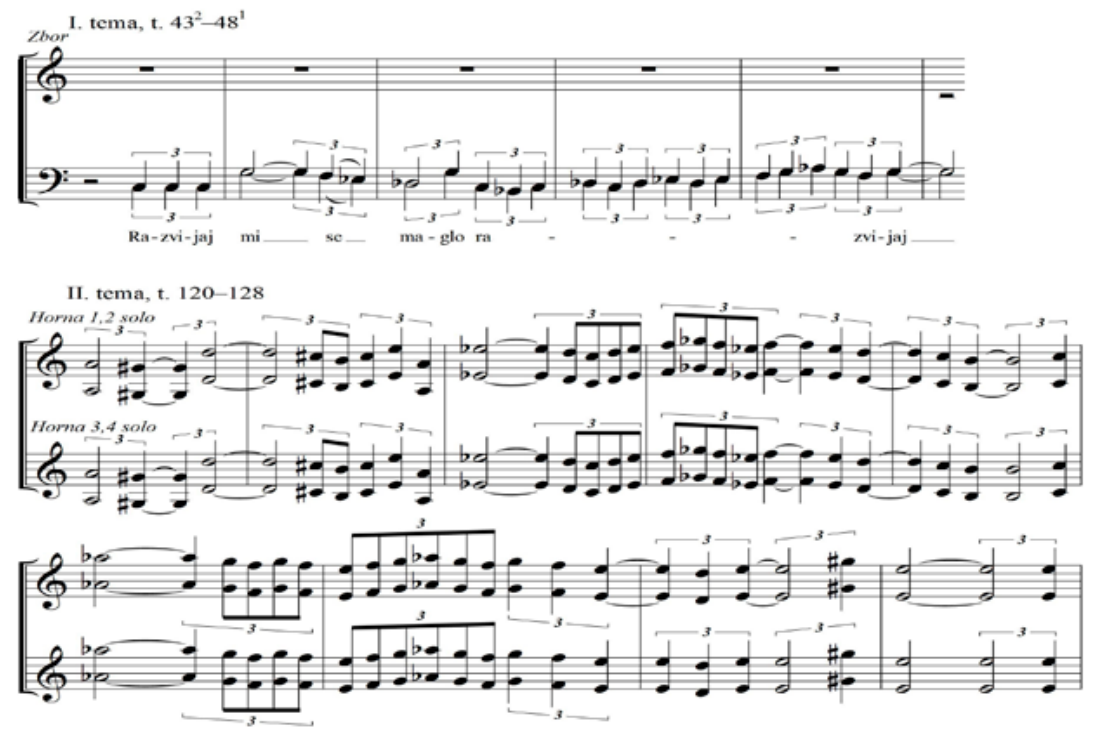

Slika 2: D. Bobić, Vukovarski requiem, Predskazanje, prikaz I. i II. teme sonatnog oblika.

Citiranje tradicijskog napjeva Tri jetrve žito žele nalazimo u uvodnom dijelu stavka i tijekom nastupa prve teme. Citat je povjeren ženskom tradicijskom pjevačkom sastavu, ali ga nešto manje nalazimo i u dionicama zbora. Još jasnija slika glazbenog oblika ove obredne pjesme doći će do izražaja u paradigmatskom analitičkom prikazu koji slijedi. Glazbeno-melodijska struktura napjeva usko je vezana uz metričku sliku teksta koju smo prethodno prikazali.

Analitički prikaz donosi tradicijsku melodiju podijeljenu na dva odsjeka. Usporedno s njom slijedi i paradigmatski prikaz citata tradicijskih motiva korištenih u skladbi.

Vidljivo je da tradicijsku melodiju skladatelj ne preuzima cjelovito ni dosljedno. Tako npr. u skladbi ne nalazimo $\mathrm{b}_{2}{ }^{(a)}$ odsjek tradicijskog napjeva.

Citirajući odabrani predložak, Bobić ostaje vrlo blizak izvornom zapisu. Ne pribjegava značajnijim melodijsko-ritamskim korekcijama. Neka odstupanja od izvorne melodije postoje pri završecima melodijskih fraza. Skladatelj izbjegava kadencirati drugim stupnjem u vodećoj melodijskoj liniji, odnosno dominantom u dvoglasju. Takav je suspenzivan zaključak odmak od karakterističnih kadenci u slavonskim tradicijskim napjevima. 

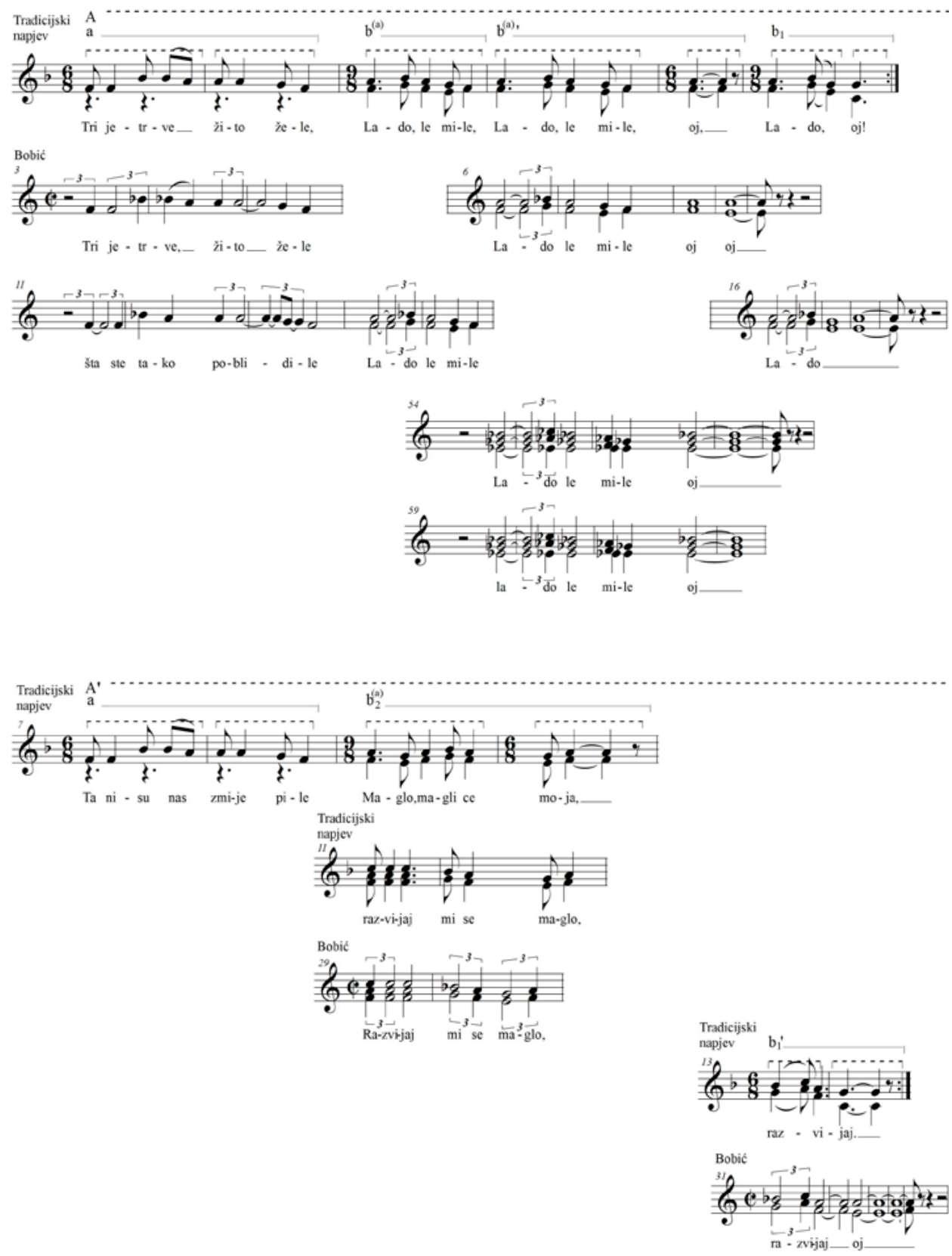

Slika 3. D. Bobić, Vukovarski requiem, Predskazanje, analitički prikaz ulomaka tradicijskog citata Tri jetrve žito žele u skladbi. 


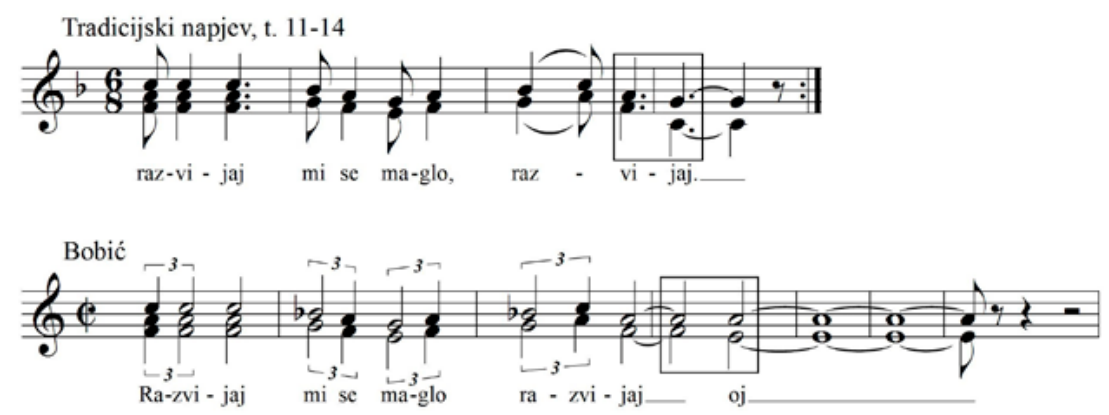

Slika 4: D. Bobić, Vukovarski requiem, Predskazanje, t. 29 - 35, melodijsko i harmonijsko odstupanje u odnosu na tradicijski predložak.

Osim neznatnih melodijskih promjena, manji skladateljev upliv možemo zapaziti i na ritamskom planu, produljenjem ili skraćenjem pojedinih notnih vrijednosti.

Značajnija Bobićeva intervencija pri citiranju očituje se odabirom mjere. Tradicijsku melodiju, izvorno zapisanu u složenoj dvodijelnoj i trodijelnoj mjeri (6/8 i 9/8), skladatelj vješto, uz pomoć triola, uklapa u jednostavnu alla breve mjeru. To će tijekom citiranja rezultirati stanovitim metro-ritamskim odstupanjima. Već je u prvom taktu vidljivo da je skladatelj motiv izvornog napjeva metro-ritamski preoblikovao u anakruzan, odnosno akefalan motiv. To nam potkrepljuje sljedeća slika.
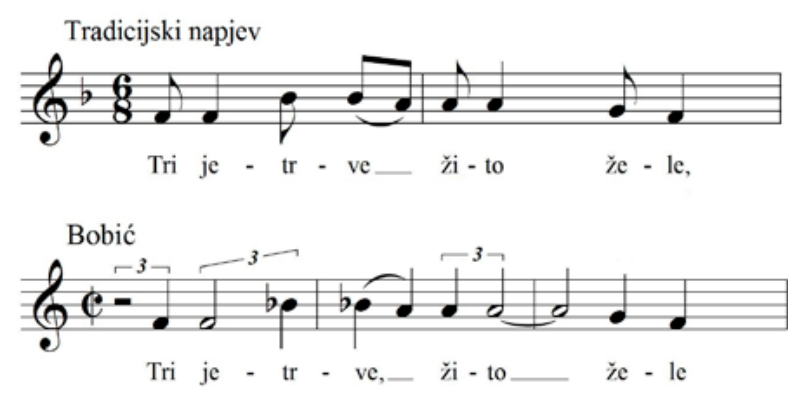

Slika 5: D. Bobić, Vukovarski requiem, Predskazanje, t. 3 - 5, metro-ritamske razlike tradicijskog i skladateljeva motiva.

Novonastale promjene $\mathrm{u}$ akcentuaciji unutar motiva rezultirale su nastankom vertikalne polimetrije. 


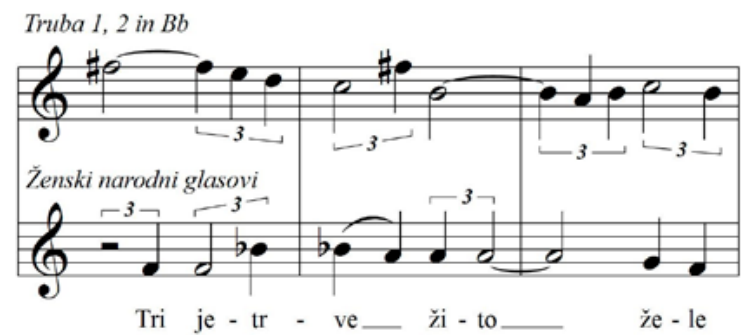

Slika 6: D. Bobić, Vukovarski requiem, Predskazanje, t. 43 - 47, primjer vertikalne polimetrije u simfoniji.

Nakon uvodnog citiranja tradicijske melodije zbor donosi prvu temu u frigijskom modusu na tonalnoj osi $C$ (t. 43). Utjecaj tradicijskog citata ovaj se put ne odražava melodijom, već tekstom (razvijaj mi se maglo, razvijaj). Glazbene razlike između izvornog citata $(\mathrm{t} .11-14)$ i Bobićeve prve teme evidentne su.

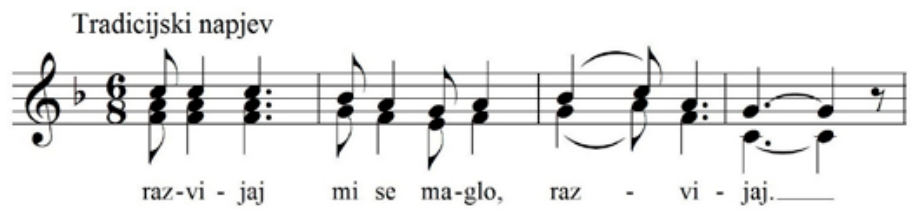

Bobić, I. tema

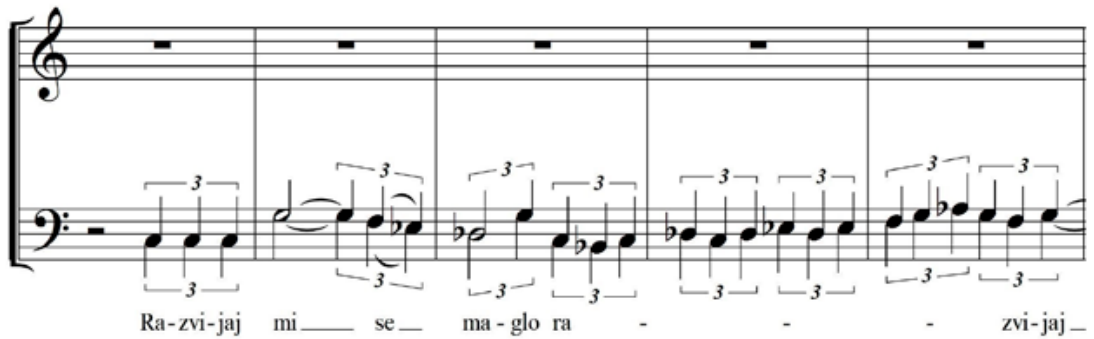

Slika 7: D. Bobić, Vukovarski requiem, Predskazanje, t. 43 - 47, glazbene razlike između tradicijske melodije i I. teme sonatnog oblika.

Citiranoj tradicijskoj melodiji u tonalitetu dokumentiranog Njikoševa zapisa (F-duru) skladatelj već od početka skladbe suprotstavlja pedalni ton A, povjeren dubljim orkestralnim sekcijama (t. 1 - 18). Nastanak frigijskog modusa na tonalnoj osi A značajniji je Bobićev upliv u etos ove tradicijske melodije. Može se pretpostaviti da je skladateljev odabir ovog modusnog prizvuka nije slučajan. Dočaravanjem emocija, ljudskih strasti i borbenog nagona koje frigijski modus izražava potiče se empatija prema proživljenim strahotama grada Vukovara i njegovih stanovnika. 


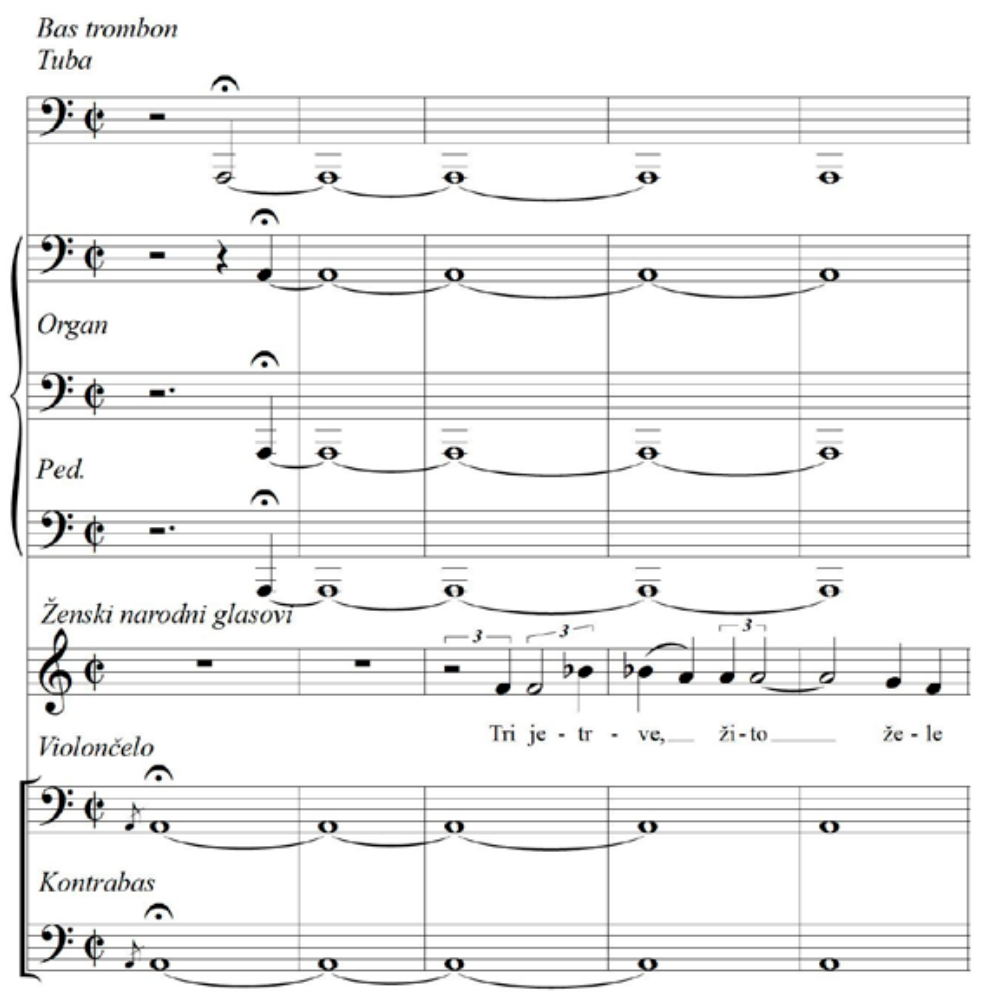

Slika 8: D. Bobić, Vukovarski requiem, Predskazanje, t. 1 - 5, frigijski modus na tonalnoj osi $A$.

Citirajući tradicijski predložak, Bobić povremeno rabi stanovite skladateljske tehnike. Tako se u t. 29 - 35 javlja bitonalitetan odnos među dionicama. Citatu u F-duru, povjerenom ženskim narodnim glasovima, suprotstavljen je frigijski modus na tonalnoj osi A u gudačkoj sekciji. Tonalitetno-modusnu dualnost harmonijske prirode susrećemo kroz cijeli prvi stavak ove simfonije.

Od t. 63 skladatelj više ne koristi motive tradicijskog citata. Identifikaciju sa slavonskim melosom pronalazi u vlastito oblikovanim glazbeno-tekstualnim sadržajima, poput melodije u glissandima, koju donose ženski narodni glasovi u t. $103-108$.

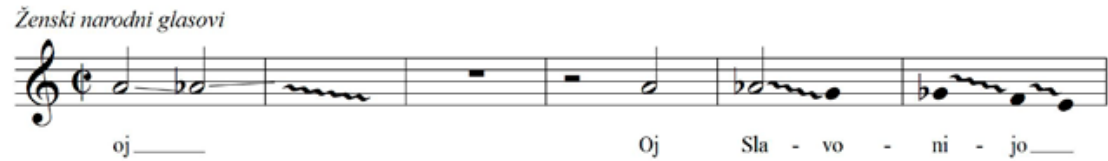

Slika 9: D. Bobić, Vukovarski requiem, Predskazanje, t. 103 - 108, stvaranje prizvuka slavonskog melosa melodijom u glissandima. 
Tercni odnosi, korišteni pri oblikovanju zborskih dionica u t. 112 - 116, također su na tragu stvaranja asocijacija slavonskog melosa. Ritamska građa bliska je ritmu korištenom tijekom citiranja tradicijskog obrasca.

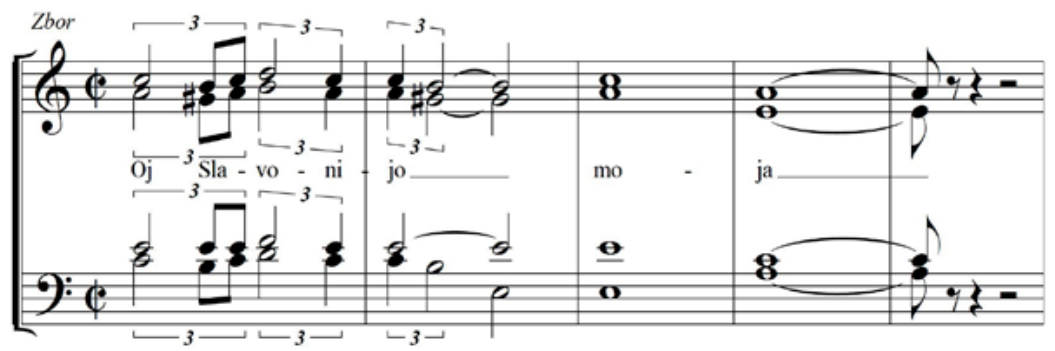

Slika 10: D. Bobić, Vukovarski requiem, Predskazanje, t. 112 - 116, ilustriranje slavonskog tradicijskog prizvuka oblikovanjem tercnih odnosa u dvoglasju.

\section{Zaključak}

Simfonijsko ostvarenje skladatelja Davora Bobića pod naslovom Vukovarski requiem pripada glazbenom opusu nadahnutom slavonskom tradicijskom glazbom. Obilježja slavonskog melosa nalazimo samo u prvom stavku, naslovljenom Predskazanje - Nagovještaj zla. Ključni element u identifikaciji slavonskog melosa primjena je vokalne tradicijske melodije Tri jetrve žito žele. Istovjetan dokumentirani zapis citirane melodije unutar prvog stavka nalazimo u baranjskom selu Dražu, koji je zabilježio melograf J. Njikoš. Može se pretpostaviti da je Bobić posegnuo upravo za navedenim zapisom pri skladanju svoje simfonije. Citate tradicijskog napjeva nalazimo u uvodnom dijelu i ekspoziciji prvog stavka, pisanog u sonatnom obliku. Tijekom provedbe i reprize citati nisu uključeni.

Citiranje vokalne melodije vrlo je blisko izvornom zapisu. Vidljiva su manja melodijska, metro-ritamska i harmonijska odstupanja, koja značajnije ne utječu na prepoznatljivost odabranog predloška. Iznošenje citata skladatelj povjerava ženskim narodnim glasovima, koji karakterističnim grlenim načinom pjevanja dodatno naglašavaju prisutnost slavonski melos. Takvo Bobićevo nekonvencionalno idejno rješenje zasigurno je iskorak na području hrvatske umjetničke glazbe.

Tijekom citiranja tradicijske melodije napuštena je dvodijelna i trodijelna struktura taktova izvornog zapisa (6/8 i 9/8). Primjenom triola skladatelj donosi citate u jednostavnoj dvodobnoj mjeri, čime je metrika tradicijske melodije samo djelomično narušena. Snažnije uplitanje skladatelja vidljivo je kod preoblikovanja početnog motiva izvornog napjeva u anakruzan, odnosno akefalan motiv. Pored melodije tradicijskog napjeva, slavonski prizvuk skladatelj nastoji 
ostvariti i preuzimanjem teksta napjeva, bez melodije, ili dodavanjem novog teksta koji sadržajno upućuje na slavonsku tematiku.

U ovom Bobićevom ostvarenju nalazimo elemente glazbenog izričaja 20. stoljeća, poput primjene vertikalne polimetrije i uspostavljanja bitonalitetnih odnosa među pojedinim dionicama. Tradicijska melodija jonsko-miksolidijskog tipa obogaćena je utjecajem frigijskog modusa.

Unutar cjelokupne glazbene građe nastale pod utjecajem slavonskog melosa Vukovarski requiem jedino je simfonijsko ostvarenje. Posebno značenje ovoga djela jest i u njegovoj tematici - odavanju spomena patnji i herojskoj borbi grada Vukovara u Domovinskom ratu. Skladba pripada opsežnijim skladateljskim ostvarenjima iz opusa nadahnutog Domovinskim ratom i zasigurno je značajan doprinos hrvatskom umjetničkom glazbenom stvaralaštvu.

\section{Zdravko Drenjančević* \\ Vocal Quotations of Slavonian Melos in Vukovarski Requiem, the Musical Composition by Davor Bobić \\ Summary}

After the First World War, with the appearance of the neo-national musical direction, the period of a more significant use of Slavonian melos ${ }^{10}$ in art music began. Though varying in intensity, it has been present since the $1950 \mathrm{~s}$ until today, so that the musical opus inspired by Slavonian melodies includes over 60 compositions. As a part of our research of this opus, we singled out a composition by the composer Davor Bobić called Vukovarski requiem. The composer was inspired to create this four-movement work by the ravages of war that the town of Vukovar suffered during the Homeland War. Within the opus inspired by Slavonian melos, only the first movement of Bobićs symphony, Predskazanje, contains vocal quotations performed by the traditional female singing group. This aroused our scientific interest and became the subject of this paper. The composer takes over and elaborates the melody of the traditional harvest tune Tri jetrve žito žele, using the quote to emphasize that the town of Vukovar belongs to Slavonia. Having proven the origin of the quotation, we analytically presented the ways of its application and the role of the original female singing group in creating associations of Slavonian melos.

Key words: requiem, Slavonian melos, symphony, vocal quotation.

(na engl. prev. Barbara Horvatović Krstevski)

\footnotetext{
* Zdravko Drenjančević, PhD, Josip Juraj Strossmayer University of Osijek; Academy of Arts and Culture; Address: Kralja Petra Svačića 1F, HR-31000 Osijek, Croatia; E-mail: zdravko.drenjancevic@uaos.hr.

${ }^{10}$ The terms Slavonian melos and Slavonian music in this context refer to the musical features of Slavonia, Baranja and Srijem, which make up the geographical region of Eastern Croatia.
} 